\title{
Malaysia-Thailand, Beyond the New Ornamentalism in Contemporary Jeweliry
}

1. Veerawat Sirivesmas (Asst. Prof. Dr.). Department of Jewelry Design, Faculty of Decorative Arts, Silpakorn University. Bangkok, Thailand. Veerawatsi@gmail.com

2. Alias Yussof (Assoc. Prof.). Department of Contemporary Metal Design, Universiti Teknologi MARA (UiTM) Shah Alam. Malaysia. Abybga14@yahoo.com

\begin{abstract}
Towards a new perspective of pedagogical approach and constructive criticism in art practice based education, the investigation is focusing on Malaysia-Thailand contemporary art \& craft jewelry in academic area. From the traditions of national craft heritage the jewelry, silverware and metalwork is now a day almost lost its conservation to their modern people and its community. The Jewelry is representative of national artifact of high crafting. It passes through present where number of contemporary art objects and lifestyle design gadgets are already dominating new behavioral to society. From this perspective, the different between lifestyle and culture can shape up concept and identity of contemporary jewelry. Where the traditional elements can still remain in somewhere with us! Many academicians, designer makers are working and try to modernize these national prides which obtained the traditional implicit knowledge and local wisdoms. The art and design education also concerns this matter by raising many cultural topics involved into curriculum. It becomes a subject that students can reflect their role of preservation or expression on their cultural contents. The cross cultural perspective of rising perception of the author on contemporary jewelry education between Thailand and Malaysia has begun in 2008 by the invitation of Department of Fine Metal, Universiti Teknologi MARA (UiTM) Malaysia. The UiTM invited a staff (author) of Department of Jewelry Design, Silpakorn University Thailand, as an external assessor for final year student assessment. The participatory research occasionally began from that point under the pedagogical framework. Observations, interviews, critics on student artworks, were the main activity process that both of students and staff of institution also interacted according to the process of assessment. Definitely, the differentiation between the students' outcome of jewelry project in Malaysia and Thailand are obviously divergence. However, the traditional ornament of each country and cultural influences also be noticed that have been frequently inspired in students' work. The constructive criticism was always the core discussion during the students' assessment and exit meeting with UiTM department members. During year by year, there were number of improvements can be noticed not only on the students' outcomes but also the academic relationship through collaboration activities that create among two institutions.
\end{abstract}

Keywords: ornamental, metalwork, jewelry

\section{INTRODUCTION}

\section{Thailand and Malaysia, the metalwork and jewelry perspectives}

The national organization manner, the different way of craft supportive. In Thailand, many craftsmen and craft products are supported by many government organizations eg: Bangsai Royal Folk Arts and Crafts Center. The Support Art and Craft International of Thailand (Public Organization), (SACICT) and many government divisions that support and improve the arts and crafts and 
some aspects it across toward design such as Thailand Creative Design Center (TCDC). There are also others organizations in Thailand such as, the ministry of Commerce, the ministry of Industry and the ministry of Culture for examples.

In Malaysia there are also many private and government support organizations such as: Institut kraf Negara, National Crafts Institute. Malaysian Handicraft Development (MHDC), Yayasan Nur Zahirah (The Royal Terenganu Songket) The Tuanku Nur Zahirah Foundation (YTNZ), Malaysia Craft Center. Perbadanan Kemajuan Kraftangan, Malaysia Kuala Lumpur Craft Complex. Yayasan Diraja Sultan Mizan, Sultan Mizan Royal Foundation (YDZM).These government organizations also have connection among local craftsmen and institutions as networking in crafts. However, the UiTM itself also found its own business unit calls 'Segaris Art Center' where art works and design objects of alumni and postgrade students can be promoted and commercialized to the public.

That means, the traditional local craft communities are also matter that many national, government organizations are focused and playing role on. However, the important point is how these organizations can collaborate and connecting together as a network or cluster system that can deliver the true supportive to the craft communities.

\section{National Craft Heritage to Modern appreciation.}

Thus, the objectives of these organizations function are to support and promote the crafts heritage into modern market. The understanding of local people about craft product may have various approaches. Some may see as the tradition products that might not be suitable for nowadays lifestyle. The evidence of national crafts heritage has seen as collective artifacts. Some may see as a very high value of craftsmanship quality that is very distinct from industrial product. Some may see as national or even individual identity in global market. It is the hard work to highlight the arts and crafts for local people to perceive as national appreciation. That is the reason why many state and government organizations are emphasized on their cultural heritage. It is the national cultural property.

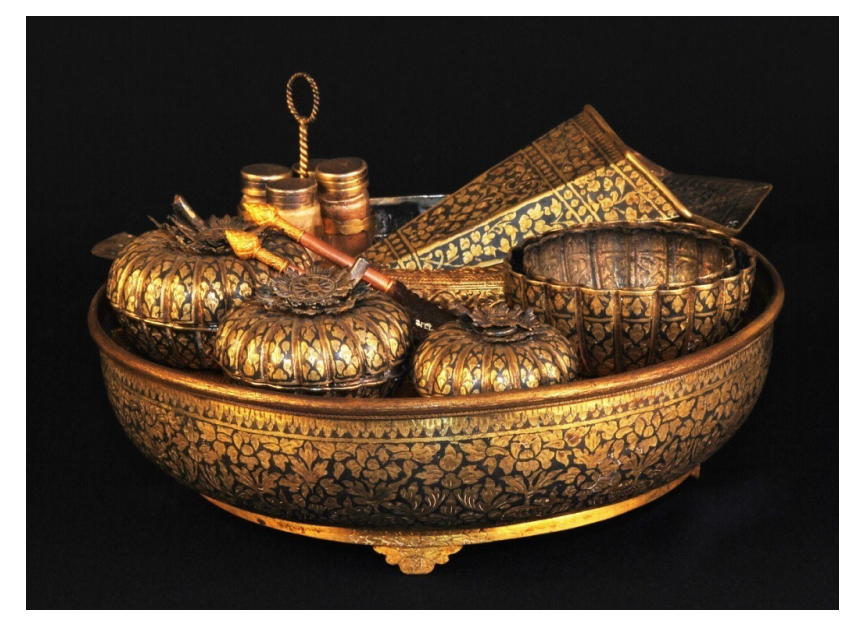

Figure 1. The nielloware with gold inlayed surface technique. Nakorn Si Thammaraj. Museum of Sociology and Anthopology, Thammasat University. Bangkok Thailand. 
bowl for merit or homage, a set of betel box or condiments. Some of tradition silverware or brassware have also found in common in the southern of Thailand and Northern part of Malaysia. Certainly, it can refer to some of cultural context relevance in some territory along boarder of Thailand and Malaysia that can be influenced.

\section{The transferring of Crafts from local wisdoms to academic institution}

The scenario of arts and crafts in Thailand and Malaysia, in another perspective, there are not only arts and crafts training just in the local area by local wisdoms as the time before. Many of them are now supported by state, government organizations. However, many other countries also have this kind of organized their arts and crafts by the government in similar ways. These are the reasons of conservation and prolong the circle life of craft products in to the national and tourist market. There is another national strategy of conserving and applying the crafts into the young generation appreciation and one of the most effective tools is to register into the education system. The early stage may be training in vocational schools as apprenticeship for craft career. Some have been repositioned into the level of university. Now a day, many art and design universities around the world provide arts and crafts disciplines in their regularly programs and curriculums.

Department of Contemporary Metal Design, Faculty of Art and Design, UiTM, Shah Alam, Malaysia. Originally named of the department could refer to the Fine Metal department. It was established in 1967 and it is one among few pioneer of art departments when Institute Teknologi MARA was found on that time. Now a day, the Metalwork and jewelry become a discipline that not many number of students applied. However, it becomes one of crafts discipline that other institutions in Malaysia want to open the program.

Department of Jewelry Design, Faculty of Decorative Arts, Silpakorn University. Bangkok, Thailand has been established in 1995 according to the high demanded of jewelry industry in Thailand. Along the twenty years of department. The number of students in take is slightly grown up. Thanks to the various inputs of team teaching, the working system that creates good academic networking from traditions to industrialize. The strong objective of institution that aims to study the history of Thais arts and crafts, and the study of present day design theories. The factor of the art and craft appreciations in young generation certainly it influences by studying that functions to connect the traditional wisdom and heritage to contemporary contextualization.

\section{A step of Collaboration}

In the field of Metal work and jewelry, these two institutions might not have coincidently working together until the UITM invited Dr. Veerawat Sirivesmas, (One of researcher and co-author of this article) to be external examiner. That should refer into 2006. As the regular assignment is to assess the final year students' projects, It has been continuing this assignment until now 2016. 
Therefore, the notice of Malaysian Metal work and jewelry under the expression of students of UiTM has been capture year by year. It is not only one way observation. The collaboration is gradually growing up of both sides. Many collaboration activities has been created and exchanged by both institutions on the first decade of collaboration such as exchanging exhibition, academic visiting, exchanging lecture and workshop.

\section{Above the views of being external examiner becomes internal data collector}

In the view of external examiner, according to the assignment, there are specific criterias that external has to investigate though out the assessment processes, such as students learning opportunities where do the project briefs provided enough opportunities to students to convey their learning process. Attainment of academic standard where the student' processes and outcome are contained a certain level of quality. Along the process of assessment brings the researchers to involve with interview with student individually.

However, not just only the duty of assessment framework the view of researchers also seen the environmental and circumstance of pedagogic approach in art and design practice based process also showed as evidences. The important is the opportunity to share opinion and experience with staff and lecturers of the department and faculty in order to improve the academic circumstance. This could be affected in both sides of institutions. The different experiences you gained is the different angles to share. This approach of over viewing is constructed the data collection and analysis process of the research.

\section{Materials \& Methods}

According to the circumstance of assessment environment, and during year by year that the authors participated and being a role part of the process. Observation and investigation on all of learning evidences are become the fundamental research method. It is good opportunities to look at the final product in very close up, in every piece and details. The outcome of assessment delivered to the department as a report form and grading.

During the assessment process, It can be noticed the independent variable and controlled variable factors. Therefore, the primary content is the assessment report of the students' performance as mentioned. Secondary content is somehow formulated during the 'tetari session' It is a casual tea and coffee time moment after assignment work among assessor and hosts (Team teaching involved). The atmosphere is allowed to talk and discuss about the subject beyond the assessment. Therefore the moment of 'flow' happened (Mihaly Csikszenmihalyi 2002). It is not just the moment of happiness 'flow' but it is also the moment of 'creativity' flows to and the pre-discussion was happened from there constructively before formally addressed on the meeting room on the day after. 


\section{Institutionalization of Craft \& Design, the new perspective of constructive development in teaching and learning process in Metalwork and Jewelry}

It might not be claimed that it was a new formular of planning the learning environment and preparing the teaching strategy. However, the 'tetari session' has somehow formulated the new idea that assessor has experiencing in his teaching and learning circumstance before and sees the new contextualization with the new environments and factors. Therefore, the new opportunities and new solutions in order to improve the students' performance and outcome that should be tried to share.

As the perspective of External Assessor, there is certain academic assessment criteria to follow. It seems to be widely and broadly scope that allowed assessor to investigate in various aspects of student works. For example, the attainment of academic standard, this criteria the assessor firstly focused on the student learning activities during the semester project. Most of the information came from interview to students. It should be proportional correspondent between learning activities and scope of project lead-time according to the other related evidences such as report, sketch book etc. Then it can summarized that how students spent (or controlled to spent) time on their project. It is about the time-based with project management. It focused on the process and quality of the process that students spent rather than the others.

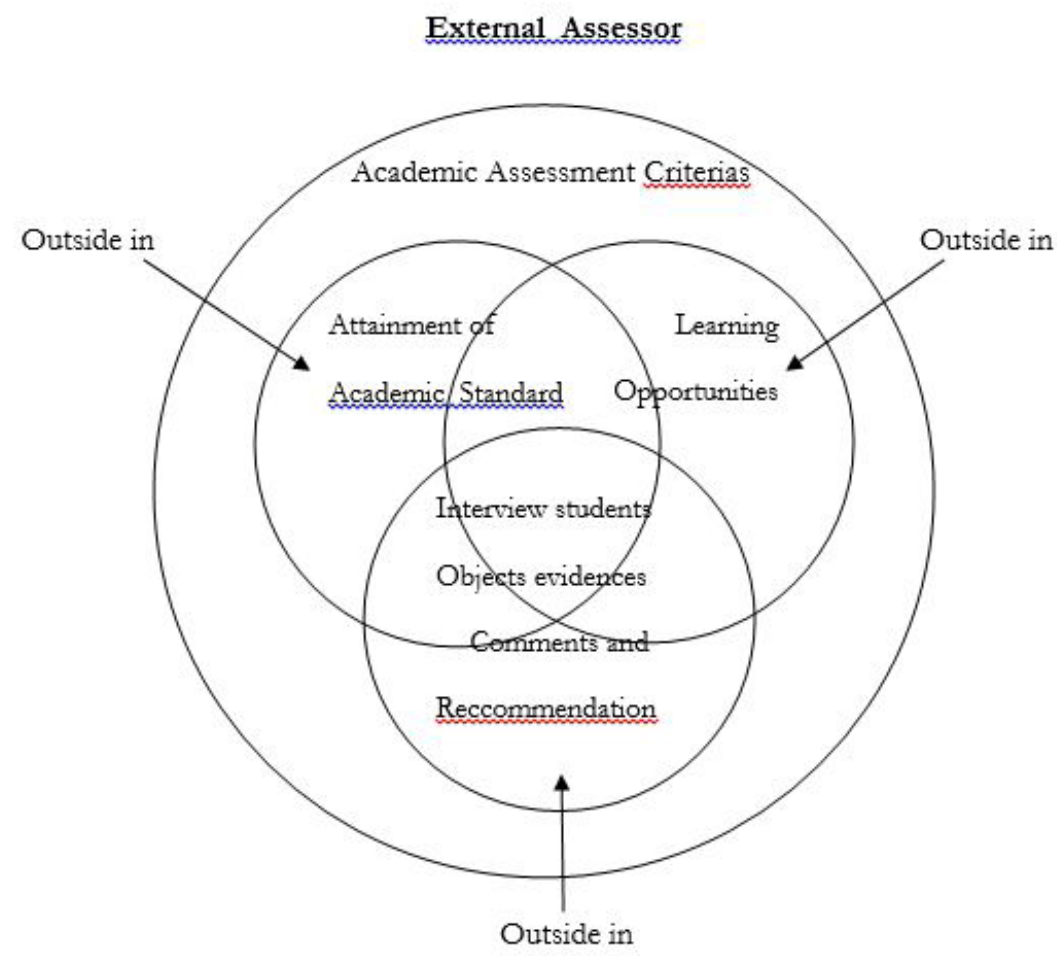

Figure 2: A model showed the role of external assessor from the point of view of author (Veerwat Sirivesmas) 
The learning opportunities, it can be highlight in to the subject matter that students selected or choose to study. Then investigated into how students open their opportunities to explore their possible of ideas. This process is in the stage of concept and contextualize of their work based on getting the project briefing. The choices of materials applied into the fabricating process are also countable.

\section{In the perspective of curriculum}

It is inevitable that when the evidences of output showed. The questions of input were raised. What was the brief of the final project(s). What is the objective of the project. How were teachers, lecturers created project. What kind of references beyond. Certainly, there were also questions to understand the course syllabus and the program curriculum. The academic objective of curriculum has ambitious and positive aims. To discuss about the improvement of curriculum may be too large scope. That take years to improve and implement that. However, understanding the curriculum and students circumstances is very important. The experimental work that can be done among the assessor and team teaching becomes the brief of the project.

\section{Beyond the brief}

Final year students have to deal with three projects and they have to be completed in 15 weeks time or one semester. The three difference brief might be slightly varies during years. However, mostly the briefs can be categorized ad one specific project such as 'microscopic elements that encourage students to explore into differences dimension of form, which becomes subject matter of students work. Second project is dealing with cultural approach. References to ASEAN cultures and countries are main focus to students. The final project is dealing with professional award that inspired into the students project. The highlight is focused on the cultural inspiration whereas students explored and experimented a lot on their works.

Each project could divide into 4-6 weeks of lead-time. Almost of them were overlapping to each other project. It's inevitable that some of project was well treated than another. Depended on students' interested too, this matter will be discussed later about the number of the projects and how it can be arranged.

According to the project brief, students have to define their own subject matter under the brief. The subject matter somehow might not be different from the others because of the theme of the project for example, microscopic elements, many students end up with few subject matters and some of them used the same subject matter (chromosome form, DNA spiral form, multi dots form). On the other hands, the ASEAN culture project, teacher tried to arrange students when selected countries (there are 10 countries in ASEAN community). Therefore, not many students use the same subject matter. That is the cause of repetition of subject matter. 


\section{Design Direction}

Once the students got their subject matter and started to do some context and visual research. The early stage of key visual collected might not differ. The question was started again on design development, where it can convey student to may be different design direction or even the similar way of direction. This matter of how to guide students to explore their design direction might be focused on the teacher or instructor. Many design process of student went distortion during design development process. Somehow the drawing or sketch design could not be lead in design development. The experimental of three dimension prototyping should be the good solution.

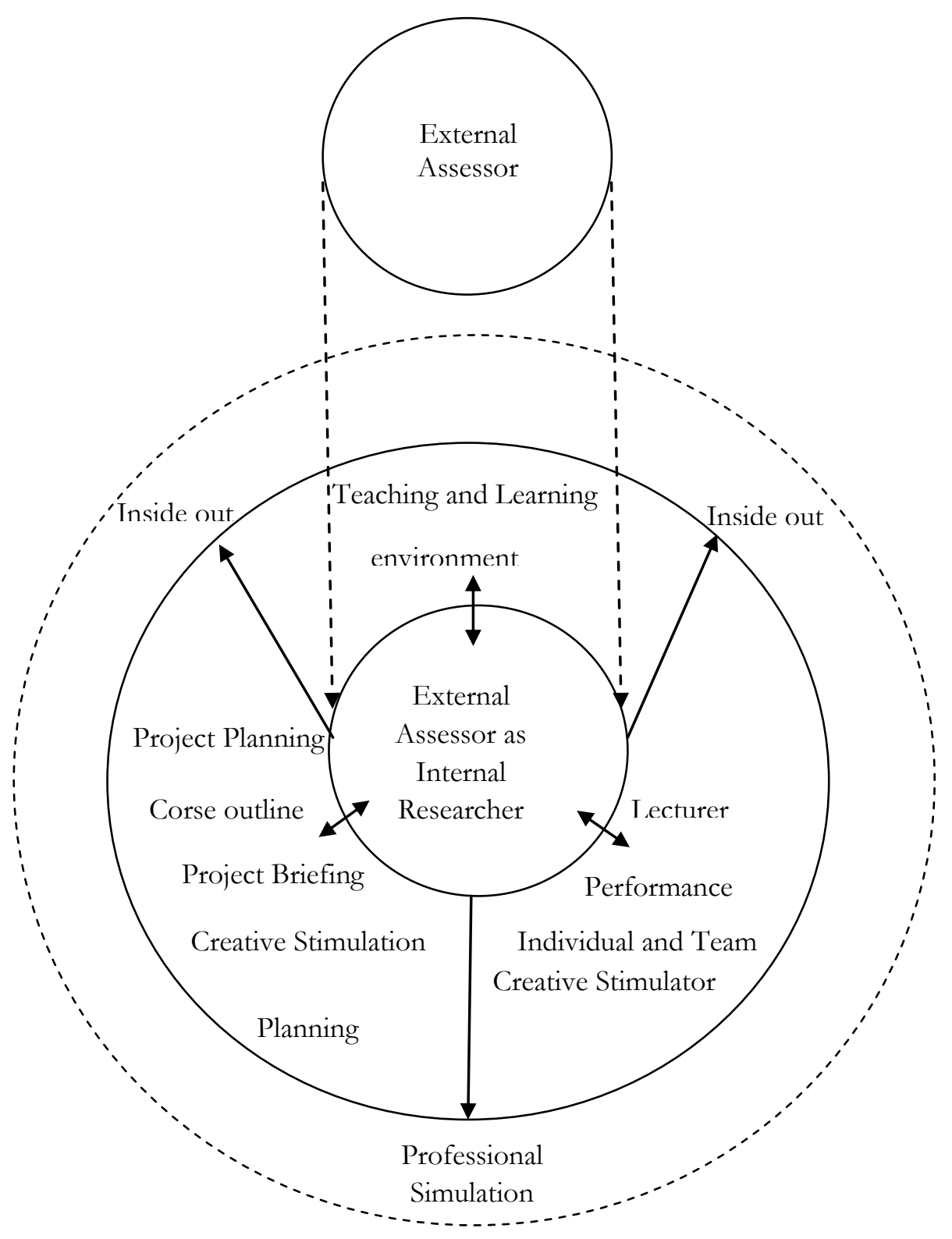

Figure 3: The model explained the how external assessor becomes internal researcher the 'inside out' arrows indicated the interchanging data and constructive discussion are played role. (Veerawat Sirivesmas) 
The figure 3 described the angle when the external assessor becomes the internal observer or researcher. Based on the assessment criteria which looked like to be the framework to evaluate students, on the other hands, it returned and reflected back to investigate the academic circumstances, teaching team strategy and also project curriculum. The outer and greater perspective of this model can help to look through every single element in teaching and learning process not only students and teacher but also the academic circumstance and its contextualization.

\section{Experimental prototyping, another approach of design development}

Beyond the brief, curriculum planning, and design direction many topics have been raised during the assessment and discussion. As it has been mentioned that the sketching process is not only way of design development, to encourage students to do more experimental work it needed to discuss with the team. Pro-Con, Weakness and strengthen approach of each design process has been discussed. The three dimensional experiment can help student to explore their out-line sketch drawing into actual form. It was the first time that students can meet their object in realization. The appropriate dimension of the product should be considered. Students also knew how to plan and manage their fabrication process based on time management. The further materials experiment and technique could be help student to define more right things. How students can manage if their fabrication process would be engaged with forming, raising, forging, piecing, chasing, or etching, patinationg.

The mock up model making is an important process that supported students to clarify their works. It is a crafting process that could enhance into pre-industrial fabrication.

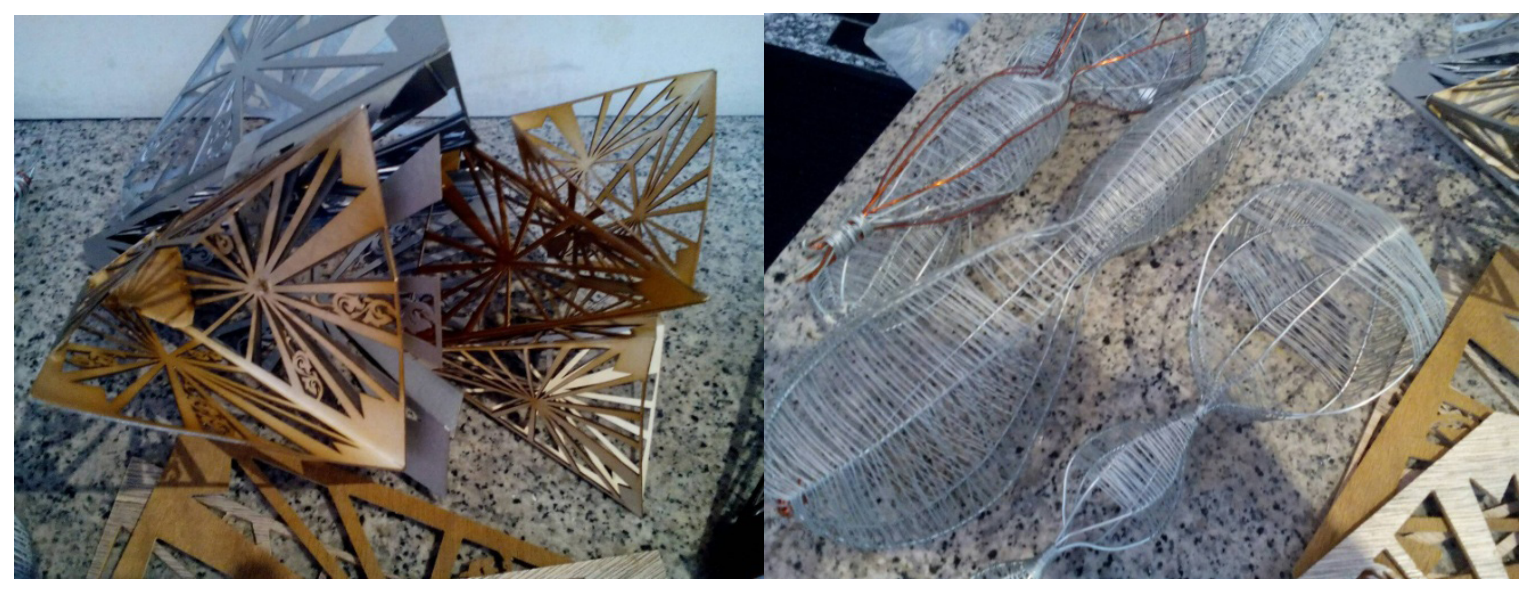

Figure 4: The evidences of experimental mock up model, pre-prototyping from students of UiTM Shah Alam, Malaysia. 


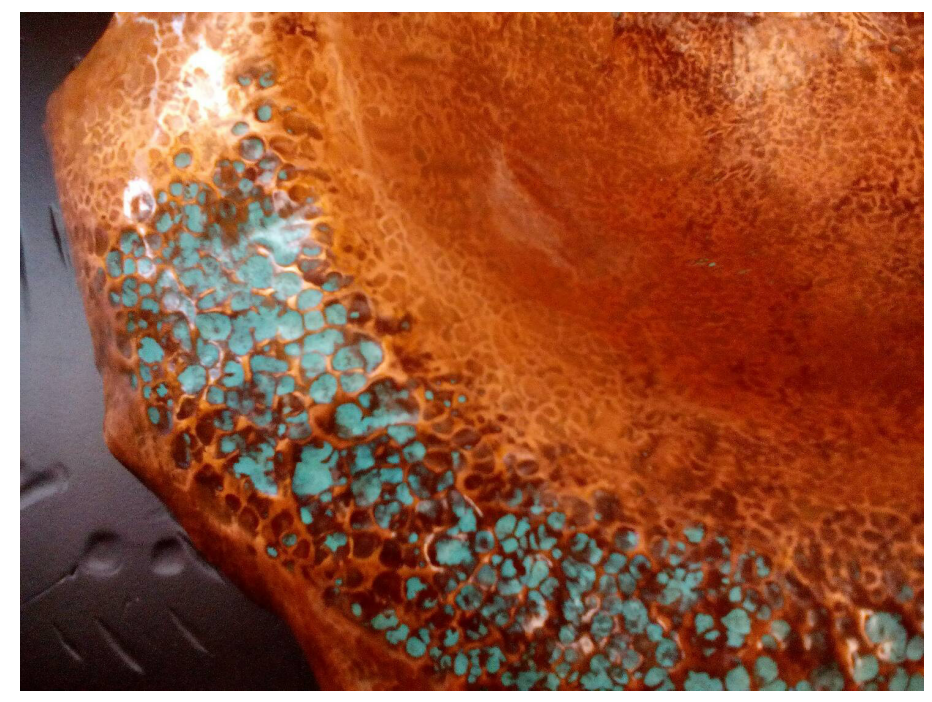

Figure 5: The close up of surface treatment by hammering to create form and texture on metal. The green color effected by oxidizing chemical to patinate the metal surface. (Work of student, UiTM Shah Alam. Malaysia) source by author

\section{Results}

The evidences of the result, firstly, it can be noticed as the art work objects.

Secondly, the result of the improvement of course out-line and teaching method. As the artworks' evidence. The figure 6 showed the outstanding of student work. One came from the microscopic elements where students can describe the subject matter (a selective of microscopic creature) and interpreted it into metalwork made from copper sheet. The student worked on the surface and texture creation. The outcome contained standard quality of craftsmanship and the form that simply connect audience to understand the subject matter.

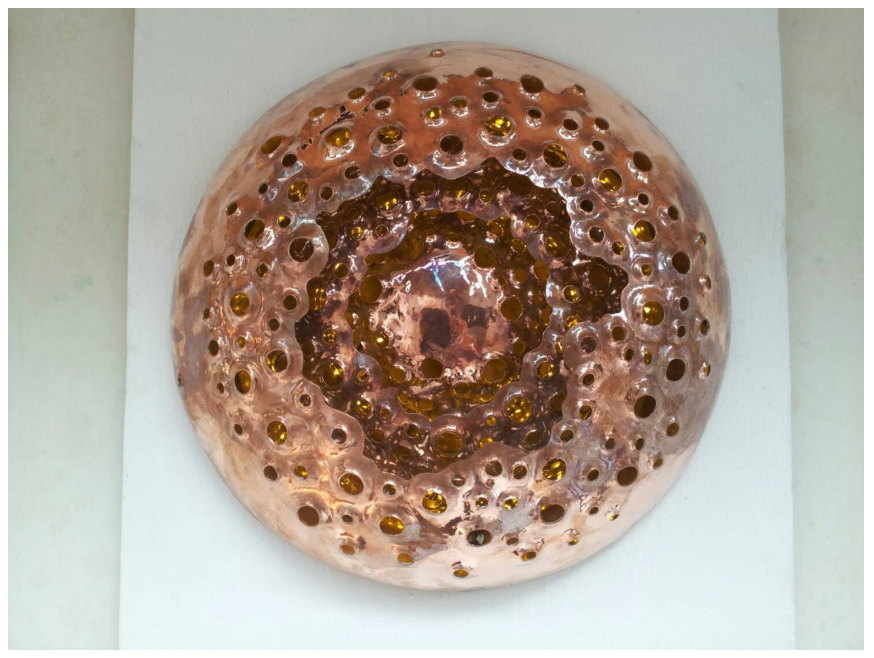

Figure 6: The image showed the completed work that student used the subject matter of microscopic element. It showed the multi-layer surfaces with various dimension of texture. (Final year students UiTM, Shah Alam, Malaysia) source by author 
The figure 6 showed the two notorious artworks of students. These two artworks were inspired by the ASEAN culture. This subject matter can lead students to explore more history of the culture that he or she interested in. The study of ornaments and patterned also showed on the research and sketch books. The evidence showed how students applied their craftsmanship qualities into their fabricating process. The objects contained multi metal work techniques such as piercing, etching, forming, and patina. Students also applied appropriated usage function that suitable to the form and ornament creation. The lighting unit is very good example of understanding the direction of the light. The metal sheet bened and composed over-layering created nice and meaning shape. The indirect lighting effect is nicely shading to notice the texture and surface, the ornament that student created.

On the other hand, another metal work 'container' inspired by Thai ornament. Student studied the pattern and ornaments in various form. The function that student created were also unique that enhance the important of the form. The patina technique color came on the right feeling.

The collaboration among team teaching to work on the brief that inspired students to work on their process along the semester was very important. On the other hand, the effort of students that contributed on their project was also admired. Being encouraged and being inspired to students by team teaching is beyond expectation. Finally, the effort of students that dedicated to their final project can obviously show on the final work as evidences.

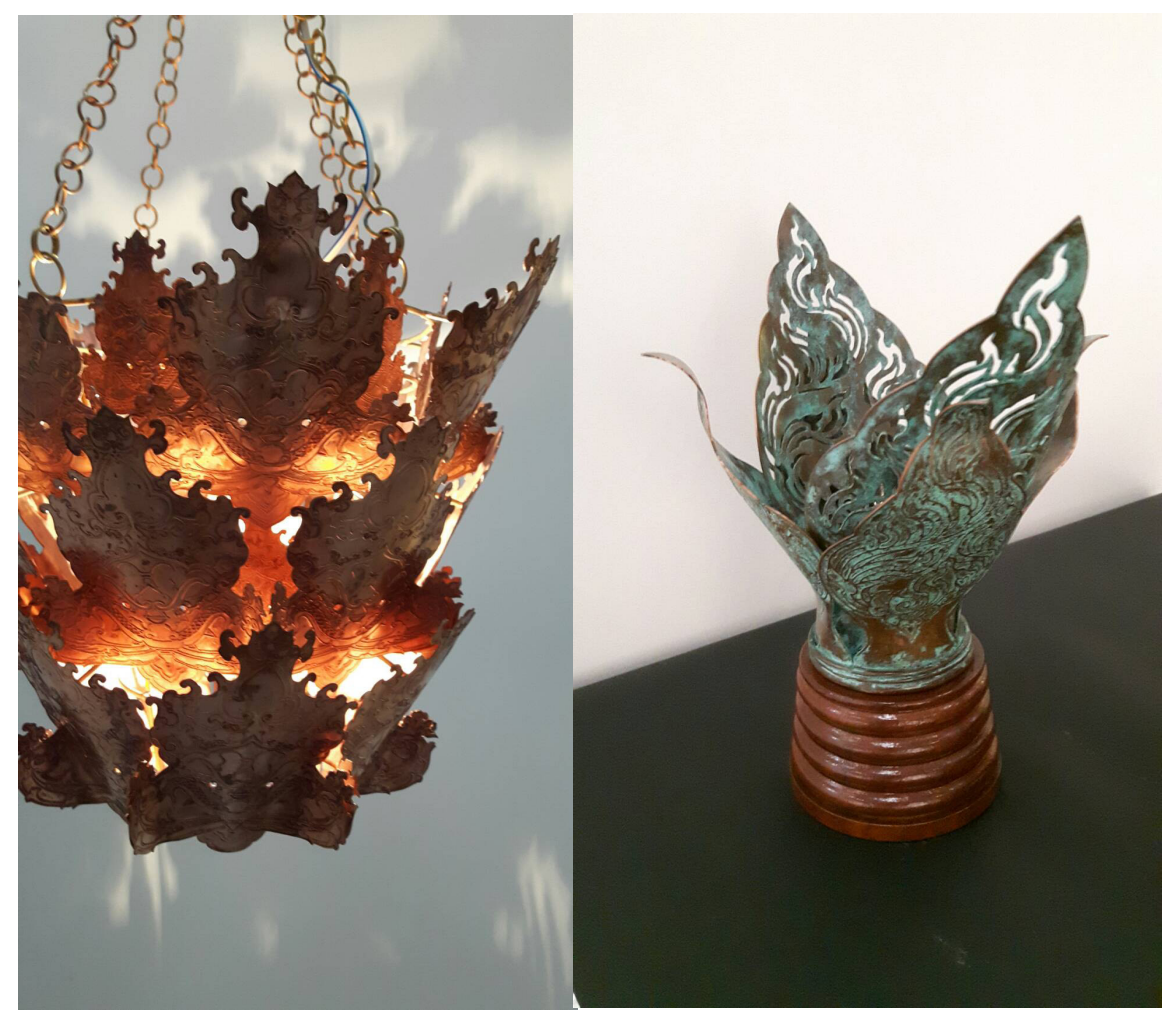

Figure 7: Another images of the final project done by students. The objects showed clearly evidence of cultural ornaments that become main eye focused of the object. It can lead the audience to understand the context of the project involving with cultural matters. 


\section{The adjustment of course outline and teaching process}

There was no document of syllabus to show the evidence how team teaching improved their course out-line. One of the comments was the time management of each project. Teacher should strategically help their students to arrange their studio time by indicating different dead-line of each project. That would avoid the overlap traffic of project in the workplace. The results was quite satisfied.

\section{Uncontrolled factors}

Certainly, many research project, there should have some of uncontrolled factors happened. In this case the Dependent factor that has been discussed was about the brief planning and the team teaching strategy. However, Students learning behavior was become major factor of excuse. Due to the UiTM allows to have two time in take students per year. One might be recruited the standard quality of students. Another semester the program could collect the in-take students that might not have passion on their study. The problem could be solve strategically by teaching method. This might be further study.

\section{Discussion \& Conclusion}

As the topic addressed above 'Malaysia-Thailand, beyond the new ornamentalism in contemporary Jewelry', the result of investigation by interviewed and observation scoped can be depicted by its outcomes. The strategic planning of lecturers and instructors were aimed on the important of its cultural heritage in their national crafts, in particular metalwork and jewelry. Therefore one of the Projects was driven in that direction. It opened opportunities to students to approach and explore creativity in cultural scope. Many of final projects came out with inspiration from the various traditional patterns and ornaments. The ornamentalism was named after the academic outcome appearances and it gradually clear year by year that many students were highlighted on the visual elements of their cultural representations. The cultural ornaments become the majority surfaces of metalwork.

\section{The quality differentiation from traditions to contemporary}

Therefore, beyond the metal surfaces, there are also concept establishment, research and fabrication process that has been done. Certainly, in term of traditional fabrication and high craftsmanship, the traditional old master and the local wisdoms are obtained higher standard quality in comparison to academic student work. Therefore, there is more room of improvement tasks to get closer or even better fabrication quality in near future. First of all, the implication of time duration and practice based methodology of craftsmanship in academic course syllabus. Secondly, the technology and craft exchange, how the practical training and studio workshop would change if the academician could invite the old traditional masters or local wisdoms come to give a lecture and demonstrate their working process! That would be positive and qualitative learning approach. The academic and local wisdom interchanging knowledge, some of old master can 
come to the institute, or even staff and student and visit and workshop on craft site.

\section{The craft and technology impacts: the direction to creativity solution}

On the other hand, the technology advancement which however, the academic institution could easily access. It could consider that which kind of technology approach would suitable to apply into traditional craft improvement. The technology can support to the craft production in consideration to both traditional conservation and the modern craft quasi-industrialization. Therefore, there are also 'pro' and 'con' in terms of the quality differentiation which leads to the new strategies and new action plan for improvement both of academic circumstance and traditions craft conservation.

\section{The changes that occur in nature of the work: Local tradition, Institutionalization}

As the resulted was evaluated in the scope of academic framework. The improvement of learning outcome, many of student works can show their enthusiastic during fabrication thought out the quality of the product. To create the brief that related to the traditional craft situation. It is very positive initiation point to create the quality design brief under the scope of academic circumstance to encourage the seeking of cultural Identity through art, craft and design objects. Especially, the enthusiastic element that occurs to the younger generations, that quality is the psychological core element to create and shift both of their mind set and their action into new appreciation and implementation to their modern society.

\section{The new interpretation and the stimulation of Creativity:}

From the perspective of researcher, there were core important factors which lead to the new stage of improvement. One is staff, another is students. The first one, there is a tool calls the exit meeting, it is a session among staff that lead to all of open mind discussion among lecturers and external examiner, the open mind during the discussion to see the weakness and strong points. Some aspects should be improved; some should be emphasized for examples, the content of the project brief, and the lead-time of each project. Even the detail of teaching process of design development and the important of mock up prototyping should be showed as students' experimental process. The revision of lesson planning or even teaching method has been collaborated. It is the important of strategic planning of course syllabus and the significant of teaching methods. Second element is student and their outcome. The senses of Malaysian contemporary metal design seen by students' outcomes are relatively connected with cultural identity. This process is a kind of course outline adjustment (might be easier than curriculum improvement, author). It works among team teaching and certainly above the brief before comes to students. This is a strategic planning for stimulation and inspiration of creativity. That is the process whereas students 
could be implemented along the program. The process of learning and outcome are evidences under the academic framework, the institutionalization and the important thing is the enthusiastic quality that occurred to students during the project proceeds.

Therefore, this research is about the perspective of Thai researcher in collaboration with Malaysian team teaching (Contemporary Metal Design, UiTM Malaysia). On the other hands, another perspective from Malaysian team to view Thai contemporary jewelry and metal design should be proceeding in near future. It is not a comparative study. It is about collaboration and the creation of constructive criticism among two institutions. In order to review and see each other to improve not just teaching and learning method and outcome, but also to strengthen the academic collaboration. The important element that becomes core of the project is the enthusiastic quality in learning process. Once it occurs in student's mind it can create massive creativity in mind and in action. That is very important to the student learning outcome quality. On the other hand, the enthusiastic quality can be occurred to the staff themselves too. Especially, on the collaboration activity, that also leads to further fruitful activity among individuals (staff) participants (students) and institutions (universities, other related institutions). Moreover, further collaboration program and activities for those two universities and our academic networking should be expanded. The project among the department of contemporary metal design UiTM Shah Alam Malaysia and Department of Jewelry Silpakorn University, Thailand, should be referred as evidence to develop more academic activities of future project. The ornamentalism visual element is representative one of expressive outcome of collaboration works. There are number of elements that need to explore and reveal. The enthusiastic quality and cultural interchange is one of the key successes.

\section{ACKNOWLEDGEMENTS}

Department of Contemporary Metal Design, Faculty of Art and Design. Universiti Teknologi MARA. UiTM Shah Alam. Malaysia

Associate Prof. Alias Yussof: Former Head Department, Deputy Dean

Dr. Haniff Khairi: Head Department of Contemporary Metal Design.

Department of Jewelry Design, Faculty of Decorative Arts, Silapkorn University. Thailand.

Ms. Tataroschong Srikulakorn: Head Department of Jewelry Design.

\section{REFERENCES}

Bangkok Fashion City. (2005). Stone on Jewelry. Bangkok Fashion now \& tomorrow. Volume. Three. Department of Industrial Promotion, Ministry of Industry. Thailand.

E. De Bono (1990) ‘Lateral Thinking Creativity Step by sStep. Harper Perennial.

E. De Bono (1999) 'Six thinking hats' Little Brown and Company.

M.Csikszentmihalyi (2002) 'Flow' The Psychology of Optimal Experience. Harper Perennial Modern Classics. California. 
IJCAS: Vol. 2, Number 2 December 2015

O, Untrach. (1998) Jewelry Concept and Technology. The Crowood Press Ltd. London, United Kingdom.

A, Young. (2008). The Jeweler's Techniques Bible. Asia: Published by Page One Publishing Pte Ltd. 